\title{
The Weakening of the Hegemon and the Future of the Liberal International Order
}

\author{
Mikołaj Lisewski ${ }^{1}$ \\ ${ }^{1}$ Faculty of Political Science and Security Studies, Nicolaus Copernicus University, ABD, Toruń, Poland \\ Correspondence: Mikołaj Lisewski, Faculty of Political Science and Security Studies, Nicolaus Copernicus \\ University, Batorego 39L Toruń, Poland. Tel: 0-56-611-2111. E-mail: mjanelski@gmail.com
}

Received: July 11, 2020

Accepted: August 13, $2020 \quad$ Online Published: August 30, 2020

doi:10.5539/jpl.v13n3p166

URL: https://doi.org/10.5539/jpl.v13n3p166

\begin{abstract}
The hereby paper presents a theoretical approach to the U.S.-China geopolitical rivalry as the process of dispersion of power from the hegemon to the challenger [Allison] that may toward, through the sphere of influence fragmentation processes, to the polycentricity of the international relations system. In this work the author presents a new theoretical approach to the U.S.-China political rivalry understood as a key element of a process of changing the model of the global hegemonic leadership, shaped most fully since 1991. The paper presents the concept of two theoretical levels - the rational strategy and the political vibrancy - which are a necessary context for identifying the nature of given decision-making processes of the main subjects of contemporary international relations. Thus, through the abovementioned concept the sino-american relations are explained within the methods that are being used by states with particular emphasis on analyzing the operations of the People's Republic of China. Furthermore, the author reasons why China is withdrawing from the use of soft power - understood in the terms of J. S. Nye's - and why it primarily uses the linking power and sharp power [Walker, Ludwig]. The article ends with a summary in which author, based on the information presented, tries to answer the question - why the liberal international order remains uncertain (or is about to fail).
\end{abstract}

Keywords: liberal international order, China, United States, geopolitics, soft power, sharp power, linking power

\section{Introduction}

It was 1991 when the world balance of power had totally changed as a result of the collapse of the Soviet Union. Closed, bipolar world has been replaced by the model of one global and inevitable hegemonic leadership [Walt 2018]. For the very first time the world security responsibility was handed over to the power that is outside of Mackinder's world island, Eurasia. There were plenty of secondary regional powers, a states dominating in the region, dictating rules and even able to influence other countries. Although the regional powers are also not power only by themselves, but by the functioning within wider regional order or security complexes [Frazier, StewartIngersoll 2010], in the early nineties the United States of America had no other real power to compete with, being in the favorable unipolar moment [Krauthammer 2002].

Within the rise of the hegemonic leadership the liberal international order and its main spheres of influence flourished to the time of the first big challenge - the war of terrorism, that - without reasonable solution - might had inhibited the liberal expansion. The Bush Doctrine and the idea of preemptive war made the West's strength more credible on the one hand, and on the other resulted in a number of negative consequences such as development of fundamentalism, nationalism, and acculturation in the region. There were a plethora of reasons for the decision on military, active campaign in Iraq. The motives came from different origins: the society needed bringing justice after 9/11, the neoconservatives suspected Saddam Hussein might develop nuclear weapon, realists were seeking opportunity to increase the power in the region [Nye 2019, 69]. Anyway, the moral resources so needed for global leadership was almost squandered by incommensurability of hard power.

Apart from the formidable international economic crisis that started at the end of 2007 it was the wake of the Arab uprising that was the second great challenge in international relations for the United States. In many terms this phenomenon was not only a consequence, but a mark of continuation foreign policy toward the Middle East. After Bush administration, while Anti-Americanism was highly spreading as well as terrorists threats, Obama tried to rebrand the older way of participating in international order. He believed that with a little bit of luck and ability to listen to others there would not be required any conflict and would be possible to lead the world safe 'from home' 
[Dueck 2015, 35-36]. Not America itself, but America with international cooperation in the formula of engaging and containment ('contagement') was supposed to be a get-everything-done scheme.

The third great challenge in IR that USA is facing for years is the rise of China within all of its the consequences for the modern balance of power, trade, arms, intelligence and technology racings and many others. This is obviously - a selective choice. It is impossible to ignore the escalated tensions with Iran, changes of the international position of the Russian Federation or relations with North Korea. However, as the presented study shows, many of these concerns are linked proximately with the problem with China or - from the wider perspective - with the problem of decreasing USA political relevance on the IR.

The main research problem of hereby work is to point out the changes in the global balance of power and therefore to identify the current state of the hegemonic leadership of the United States. As the system of IR is in many ways a self-regulating system [Keohane, Nye 1978], comparative analysis is necessary to determine the political relevance of superpowers. What is more, it is crucial to find out the character of the political actions staying behind the changes and examine whether they are a result of rational strategy, whether they are a consequence of political vibrancy.

With this comes several methodological problems. It seems that most papers devoted to IR, geopolitics and other sub-disciplines directly connected with political science are casuistic studies. They may evidence or falsify hypotheses and theories using induction or deduction methods, providing a detailed research on the specific area. To understand the ontological basis of the alternation processes in the balance of power, the measures by which these changes occur should be revealed. By the measures, however, I do not mean the exact empirical actions or tools, but the theoretical channel through they are implemented. One of such a channel - with a very capacious semantic field - is the power. The current typologies of power, primarily Nye's soft power concept [Nye: 2004] are extremely valuable, however, in the era of IT societies it seems necessary to verify them and make further typologies.

The remainder of this paper is organized as follows. First, I explain on what stages the rivalry between the U.S. and China is performing and present an empirical data that illustrate the changing of the international order. Concurrently, I show why some data from the methodological point of view should be questioned. Second, I distinguish two fields of political actions in international relations, visualizing the difference between the environment of rational strategies and political vibrancy. Relatedly, the possible methodological approaches to the analyzing above phenomenon are proposed. In the next section I present a new - or forgotten - theoretical channels of powers, i.e. linking power and sharp power that may be relevant to understand the reasons behind China's supremacy of the last - and maybe further - years. Before summarizing, I check the research questions and hypotheses, formulating a conclusion of the gradual collapse of the liberal international order.

\section{The U.S.-China Rivalry}

Since the socio-economic reforms in the late seventies in China, initiated by Deng Xiaoping, a historic and unprecedented increased country's development could be observed. First government programme, called 'Four Modernizations", was created in order to strengthen national agriculture, industry, science and technology, and military power ${ }^{1}$. But solving the basic economic problems, mainly related to food and supply shortages, was just the beginning. The second phase of modernization comes in the early nineties and lasts to the end of century. It brought China to the doubling GDP as well as a further economy improvements, including relevant openness extension for foreign investments and businesses. Although the transformation of a quantity-oriented economy into a quality-oriented economy is associated today mostly with the Made in China 2025 project, in 2001 (the times of Hu Jintao rules) the Go Global! initiative was created, which was intended to enhance China export as well as improve products quality. Since 1978 to 2017 China's gross domestic product had already grown about $22384 \%$ from 3678,7 to $827121,7^{2}$. The scale of poverty in China has dropped drastically since the early 1990 s. In 1990, 47.3\% of Chinese citizens earned no more than US \$ 3.20 statistical US dollar (PPP). At the same time, in $1990,24.4 \%$ of Chinese people did not earn more than 1.90 statistical US dollar (PPP) per day. It can be observed that at the turn of 1990-2014 the percentage of people earning US \$ 1.90 statistic dollar (PPP) per day decreased by $24.1 \mathrm{pp}$, i.e. $98.770491 \%$, i.e. from $24.4 \%$ (1990) to $0,3 \%$ (2014) [data from worldbank.org]. This phenomenon is twofold. On the one hand, the data show how poor Chinese citizen statistically was in the early 1990s (and even poorest before), and on the other hand, how quickly this phenomenon began to change.

\footnotetext{
1 Vide: $\quad$ American $\quad$ 'Four $\quad$ Modernizations' analysis $\quad$ from https://www.jec.senate.gov/reports/97th\%20Congress/China\%20Under\%20the\%20Four\%20Modernizations\%20Part\%20I\%20(1130).pdf.

${ }^{2}$ Vide: National Bureau of Statistics of China, http://www.stats.gov.cn/tjsj/ndsj/2018/indexeh.htm.
} 
Economically, the United States remains a leader, but her position is no longer intact. The difference between the degree of China's participation and the degree of US participation in the global economy has been systematically decreasing since the beginning of the 21st century. The total value of Chinese imports and exports was quantitatively ahead of the United States for the first time in this respect in 2013 [Pacuła 2015].

The number of Chinese patents entered in 2009 was 241,435 , trademarks 838,071. In 2018, the number of patents is $1,460,244$, trademarks - 8,118,135. For comparison, the same variables for the United States are: 397,997 patents and 1,040,068 trademarks (2009), 515,180 patents, 1,759,406 trademarks (2018 $)^{3}$. What is more, today China is the second most valuable nation brand in world, Chinese companies are well-known and

are in the group of the world highest market capitalization entities [Brand Finance 2019].

On the other hand, measuring the economy with the simplest tool, GDP, the difference still speaks in favor of the U.S., but - as I point out in the section below - it is unclear how much data can be trusted by the Chinese government (and access to data through external agencies is limited). It is already predicted that the Chinese economy (total GDP) will overtake the United States around 2029.

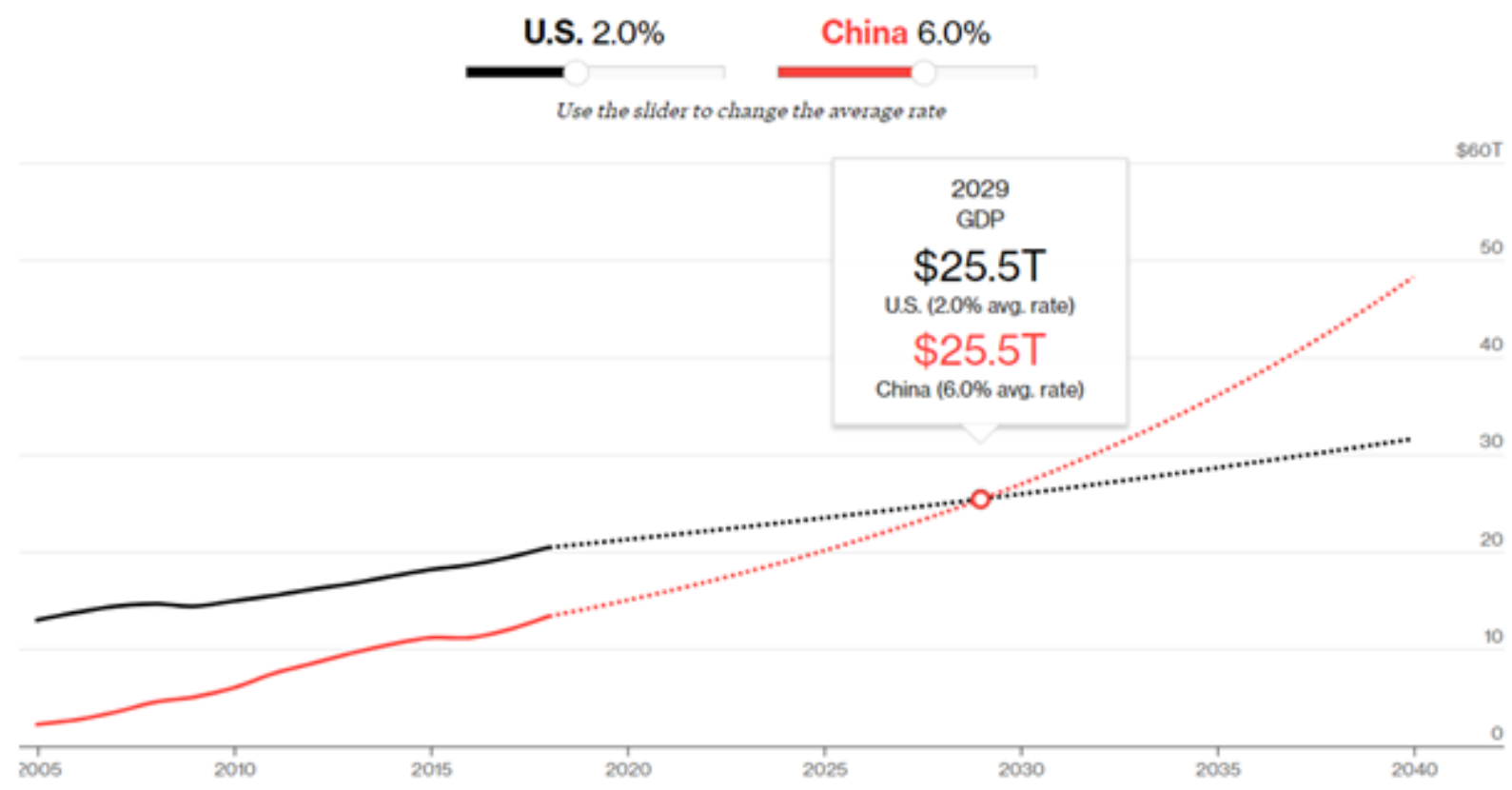

Figure 1.

Source: Scott, M.. Sam, C. 2020. Here's How Fast China's Economy Is Catching Up to the U.S., za: https://www.bloomberg.com/graphics/2016-us-vs-china-economy/.

These predictions were made just before the global SARS-COV-2 virus pandemic. How individual world economies emerge from the economic recession will directly affect further forecasts (see section 6).

For some years the phenomenon of China rise has been the headline of many political science journals, though the growth of Middle Kingdom power was already predicted in the 90. [Brzezinski 1997]. According to Bloomberg analysts, if China's economic growth rate (measured in GDP) was on average $6 \%$ annually and the U.S. economic development rate $2 \%$ annually, the Chinese economy would be equal to the US economy in 2029 [Scott, Sam 2019]. What is more, the total value of Chinese imports and exports for the first time was quantitatively ahead of the U.S. in 2013. China's share in the global economy is steadily increasing.

However, at these points some methodological problems are revealed. Is it possible that China already has a more powerful economy than the U.S.? In fact, the question is difficult to answer. Firstly, there are arguments showing the possible incredibility of Chinese GDP data, which are based on data collected by Chinese local governments that are rewarded for achieving growth targets [Chen, Chen, et al. 2019]. Secondly, China's methods of calculating

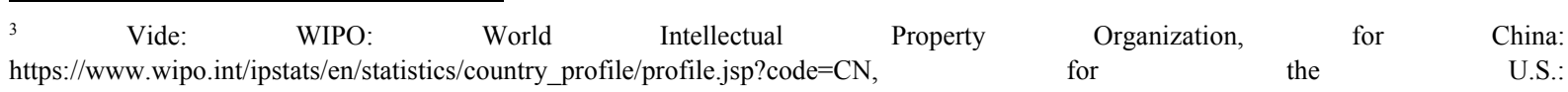


GDP are not transparent. This leads to the other side of the coin.

The main issue is the access to information. It is clear that in China's interests it is a time delaying-play. It is very well seen on the example of intended currency devaluing. Concurrently, publicly available economic data includes legal trade, and the economic value of other sources remains guesswork. What is more, even the real aspirations of Chinese decision-makers remains uncertain [Beeson, Watson 2019, 388] or successfully blurred. As a result, a scenario in which China's GDP will now or soon exceed the U.S. GDP cannot be excluded.

The fields on which China is dangerously approaching the level of the United States could be multiplied. According to Lowy Global Diplomacy Index, in 2019 China has overtaken the U.S. as the largest diplomatic power in the world ${ }^{4}$, which is unprecedented situation. Although the index illustrates the size of diplomatic institutions rather than the architecture and real diplomatic power, this change is another small example showing the seriousness of the overall international situation.

The rise of China is a factor that - a natura rei - affects the international order especially in the times of hyperglobalization and a highly interdependent world. One of a very prominent asset of being in the position of so-called challenger [Allison 2017] or just a second overall strongest country in the system is the possibility to balance the interests of other members and the possibility to balance the others' possibilities, which is much more meaningful. Many empirical examples may be found to prove the importance of the above assets. Let only recall the consequences of the hypothetic scenario in which the Chinese economy is decreasing rapidly. If the Chinese export drastically lowers, the EU market would be at a tremendous risk, because of its high level of economic dependence to China (on average China and EU trade over $€ 1$ billion a day). Not much better picture unveiled in economic relations with USA. What is more, China is much more resistant to economic crisis as it could be seen after the eruption of the recent global crisis.

\section{Between Rational Strategy and Political Vibrancy}

The vibrancy of international relations is understood as its substantive feature expressed in a significant level of the inter-state relations complexity. Due to this feature, IR are a difficult subject of prognostic or futurological analyzes. However, these definitions should be match to another phenomenon, which is called spontaneity of IR. Another use of the term is to reflect the dynamics of political processes [Friedman, Chase-Dunn: 2005]. Although the term is very rarely used in the research literature, its mean will be much closer to the proposed idea.

The political vibrancy, not related with the idea of vibrant matter [Bennett 2010], is much deeper phenomenon. Within rational strategy ${ }^{5}$ it is a one of two basic levels of political actions in the IR. While the level of rational strategy includes purposeful, orderly and conscious actions, to the level of political vibrancy might be assigned those political actions, that can be more temporal, imposed, and even chaotic. The level of rational strategy illustrates actions aimed at achieving previously planned overarching goals. The time horizon in this case can be very long. This level may include all political strategies, e.g. national defense strategies, but it is needed to be aware that publicly available information in many cases will not reflect the details of the strategy. However, these two categories partly answer the question, whether states are rational actors in IR, whether they are not [Rubin 1997]. Like a Schrödinger's cat, they might act rationally and irrationally at the same time, but in different spheres.

From the description outlined above, four theoretical models of political action (PA) can be distinguished as follows:

1) Cohesive, deliberated $P A$

2) Unrepresentative, imposed PA

3) Inadequate, chaotic PA

4) Representative, fragmented PA

This typology is a result of a simple theoretical demarcation below:

\footnotetext{
${ }^{4}$ Vide: Global Diplomacy Index, https://globaldiplomacyindex.lowyinstitute.org/country_rank.html.

${ }_{5}^{5}$ The term rational refers to the awareness and does not include normative contexts.
} 


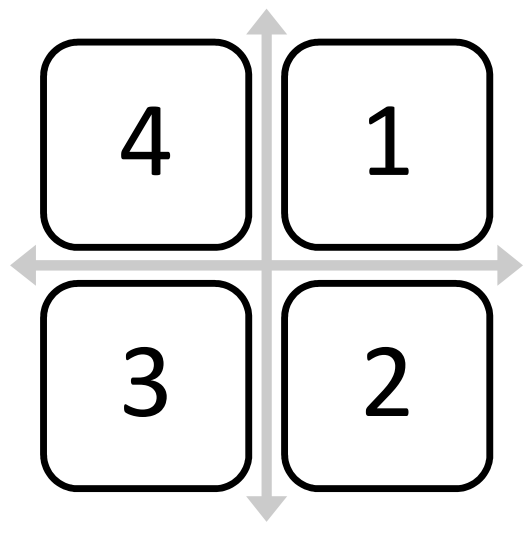

Graph 1.

The diagram above consists of two curves. The horizontal line means the degree of political vibrancy, the vertical line means the degree of rational strategy. Both lines are theoretical continuums, and all four distinguished models are a separated Weberian ideal types [Weber 1949; Lindbekk 1992].

Although they do not exist in reality in the exact formula, they can be useful in theoretical analysis of changing tendencies and illustrating the essential nature of considered political action. To justify the proposal of using ideal types, it is worth to illustrate their purpose on the example of political action in international relations.

One of the last major precedence - killing Iranian Major General of Islamic Revolutionary Guard Corps and one of the most important political figure in Iran, Qassem Soleimani - was quickly interpreted by the media as an extreme measure and deadly escalation leading to war. The causes of this event may be found in many factors.

President Donald Trump before announced that when a single American dies in a result of Iranian military actions, the U.S. will react immediately. Regardless of the statement nature - an expression of strength at the level of shaping the political power or a real promise - the next attack on the Iraqi base, which resulted in the death of an American contractor, had to cause the announced reaction. In this situation, the both spheres of political actions are presented. At the level of political vibrancy it can be see that a specific event was unpredictable, but required the United States responses.

On the other hand, relations with Iran have escalated for a long time. Since the Joint Comprehensive Plan of Action has failed and another economic sanctions were imposed on Iran, the economy and investments of this country harshly felt it [Juneau 2019]. What's more, apart from the very controversial nature of the decision to kill Soleimani (without approval from Iraq government, without the approval of the United Nations Security Council; and without explicit approval from Congress) [Morkevicius, Lupton 2020], the conflict with Iran has been legalized in a sense even by the recent official recognition of the Iran's Islamic Revolutionary Guard Corps as a terrorist organization ${ }^{6}$, therefore these actions were rather part of a planned, rational political strategy. Another arguments may be found in the specifics of the action. First of all, the precision and the place of the attack on Soleimani shows that it was not a step into the open conflict. Second, presidential speaking from the Grand Foyer of the White House from $8^{\text {th }}$ of January after the night Iranian missile attack on the U.S. military base has confirmed backing away from further military conflict and - at the same time - ceding at least part of the responsibility of the security in the region on the other NATO members.

The case of Iran and NATO represents the rational strategy of the United States as well as its approaches to China. Very good examples of political vibrancy are the US-China trade deficit and intellectual property theft which were problems for many years. These issues needed a reaction, e.g. raising tariffs, however, the reaction might not represent the level of rational strategy. This dilemma is to be continued in next chapters.

\section{Superpowers and Its Powers - Understanding China's Global Play}

It is worth for a while to analyze ways in which states (or non-state entities) exert influence on other actors of the system. The distribution of power is very relevant in analyzing what states would tend to do as well as what they are able to do (as 'power checks power') [Deudney 2017, 202; Deudney, Ikenberry 2017, 11]. The possibilities

${ }^{6}$ Vide: Statement from the President on the Designation of the Islamic Revolutionary Guard Corps as a Foreign Terrorist Organization, za: https://www.whitehouse.gov/briefings-statements/statement-president-designation-islamic-revolutionary-guard-corps-foreign-terroristorganization/. 
itself, in fact, are more important than political goals. Besides, the term refers also to the 'power transition' perspective, which seeks a simple dependence of cause and effect in international order and the rise (and fall) of superpowers [Ikenberry 2018].

In a wider perspective a global distribution of power determines the type of international order [Mearsheimer 2019]. In more narrow concept a distribution of power is understood as a division of powers that states use in order to achieve its purposes. Essentialising these powers is a key to realise the states' methods and its ways of approaches to the others.

For millenniums people have known many ways of achieving their goals in the relations with others - brutal force, extortion, diplomacy, trade, mutual benefit, spreading culture or even intended shifts in religious landscape. Some ways are still prevailing, others are obliviated. Probably one of the most relevant idea of distinguishing power is the concept of soft power [Nye 1990; 2000, 2002; 2004]. This theoretical category determines the schemes of actions, the way states - but mostly superpowers - influence each other. The measures may be different, but the common denominator is its nature and purpose - Nye's soft power is 'the ability of a country to persuade the others to do what it wants without force or coercion' [Ikenberry 2004]. In other words, it is 'the ability to shape the preferences of others' [Nye 2004] in order to get what is wanted, and within other's will. Due to soft power methods, the attractiveness of one actor in the eyes of others increases, and therefore using the other kind of mechanisms, e.g. carrots and sticks [Nye 2004], may become even unnecessary. Under soft power political effects may be obtained without direct impact. The power is functioning indirectly by influencing other actors at different levels. While hard power, which may be used to achieve goals directly and without any consent of the others, is realised with force, sanctions and any other means of coercion, soft power uses values, culture, institutions, policies and relationships.

Considering there are many varied sources of the ability to attract others, the conceptual framework seems to be almost endless, which is why the idea should be partly questioned. Over the years the concept of soft power has been arranged in a plenty of fields. The soft power resources may be found in many spheres and states' activities - public diplomacy [Nye: 2012], cultural policies [Otmazgin 2012], strategic narratives (or meta-narratives) [Miskimmon, O’Loughlin, Roselle 2014], language using by representatives [Hill: 2014], higher education [Trilokekar 2010] and international education [Sayamov 2013]. The soft power may be generated also by the activities of politicized orthodox church [Hudson: 2018] as well as by global sport events [Grix, Houlihan 2014].

I believe that categories of soft power resources may be easily reclassified. On the level of axiological values the state may attracts another state by its leading religion, ideology, and the kind of culture (e.g. individualistic, collective). On the level of ontological basis there are such a factors like human rights, security, freedom of speech, alleviation of poverty and many more. On the level of epistemological values the other factor is the leading social inclusiveness or social exclusiveness, and the degree of the society's acceptance for those who differ.

The fact that the concept can be transformed almost effortlessly indicates inaccurateness of its conceptual framework. One of the most crucial soft power resource is widely understand culture. It might be high culture, popular culture as well as so-called universal culture. But in the deducing process it is not the end. Among high culture the activities and relevance of universities, operas, theaters, cinemas and many other important centres also might be a next part of deduce. Although one of the above resources might generate only an indistinguishable level of attractiveness, it should also be pointed out, in order to get a holistic viewpoint. This - with the high transformability - suggests the idea might be too broad semantically. The Nye's concept of power has been met with scholars' almost enthusiastic approval and - with its simplicity - it is almost splendid, but on the other hand it tends to be overused.

In addition, Nye also distinguished smart power, 'which is neither hard, nor soft - it is both' [Nye 2004]. The approach determines the need for a strong army, and thus investment in alliances, partnerships and international institutions at all levels to increase their own influence and verify the legitimacy of action [Armitage, Nye 2007 7-11]. Actually, there is only one methodological doubt - so constructed approach suggests that the dilemma is completed and all types of state powers are defined.

There are some political actions that are difficult to incorporate into Nye's concept as they function on a different grounds. Analyzing the IR at least two other powers may be identified. The first type includes a states' political activities that are intended to reduce the alternatives of the second actor. They are usually carried out in a peaceful manner. In order to obtain a preferred result the one side limits the choices of the other's. One's purpose may be achieved without coercion (at least direct ones) and not necessarily because of its attractiveness, but because of other player's no better choice at the moment. This kind of actions may be tentatively named as the linking power. Whereas hard power changes what others do, soft power shaping others' preferences in what to do, the linking 
power changes and limits the others' checkboxes.

In fact, the linking power is the very well-known phenomena that is analyzed to understand the real purposes of the states' behaviors in the IR. It is strongly connected with the 'dependency dilemma'. In a modern, hiperglobalised world the networks of dependency relationships among actors are certainly vast. Activities in the field of hard and soft powers are characterized, among others, by the fact that the actor who is the target of these activities is generally aware of this. Linking power activities may not be clear to others and may remain just a conjecture. What is required, are other actors.

The linking power is distinguished not only because it might be somehow important on the level of theory, but mainly because it is commonly used by Chinese decision-makers. In the case of today's China the linking power concerns manipulating other actors and dominating them in order to make them somehow more dependent. The great empirical example is the situation on Sri Lanka. The country's inability to clear a debt caused a 99-years lease of the Hambantota Port by Chinese [Carrai 2019]. The actions intended to make some states lack of alternatives is a very powerful, pragmatic and - from the Atlantic point of view - immoral processes that already happen. However, as the further examples shows, the methods of realising the linking power are not limited to the so-called debt-trap diplomacy.

The position of China in the international order increases also due to the Chinese expansion in Africa. 'Conquering' Africa is possible mainly because of the initial attractiveness of the Chinese offers in the eyes of African decisionmakers. While Beijing's exposure to a total African debt is reaching disquieting proportions, the Chinese investments are intensifying [Alden, Jiang 2019]. Unlike the United States or European Union the Chinese government, its national banks and cooperating financial institutions (e.g. Asian Development Bank, Asian Infrastructure Investment Bank) require neither democracy, nor respecting human rights. China is not negative toward the phenomenon of corruption that is still widespread in many African countries. Instead of this, they silently use this to corrupt elites. This ability of co-opting decision-makers is deeply rooted in the Chinese way of governing and making politics at the local, provincial level [Persson, Zhuravskaya 2011].

It is quite symptomatic correlation that where the corruption level is higher, the Chinese involvements resulted in side effects becomes more apparent. In Ecuador corruption led to the building of the Chinese-financed dam that was located at a danger place near a volcano. The problem of 'capturing elites' is clearly noticeable in a the countries belonging to the Chinese sphere of influence in the term of classic geopolitics. Such actors like Cambodia or Myanmar are not only under Chinese leadership, but practically are being steered by the endured corrupt links between leaders [Shullman 2019]. As a result, basically there are no other directions for them in the foreign policy. The abovementioned Chinese practices are by no means the exception - they may be rather analyzing as a procedural method of foreign operations.

I find the question - whether the classic Nye's soft power is using by China, whether it is just a curtain - very important for analyzing modern IR. What is China's soft power and where its resources should be sought?

The concept is prevalent in Chinese academic discourse. The applause to the Chinese Dream are presented in many scholar works but this could be classified as a little propaganda rather than real soft power's example. Chinese intellectuals write on Middle Kingdom's soft power very often [Kalimuddin, Anderson: 2018], but it cannot be a source of soft power in itself. Furthermore, there are Chinese scholarship programs, student exchange programs, development and export of one's own culture. Chinese culture is also promoted by the network of Confucius Institutes, which are present on six continents in a total of over a hundred countries [Yiwei 2016 155]. The Chinese film industry is emerging for last years as well as literature, which is more often translated to English and other languages.

One may say that the abovementioned examples are fragmentary and that, in fact, Chinese soft power is much more advanced. Indeed, there are many other examples. Probably the most prominent ones are the governmental programme, 'Made in China 2025', aimed not only at changing a quantitative economy to a qualitative economy, but also at creating a good history related to Chinese products [Wübekke, Meissner, Zenglein, and others: 2016]. Another example is a developing Chinese space programme. A leading international and intercontinental project is One Belt One Road Initiative (New Silk Road) which links two Spykmanian Rimlands - West's and East's. The OBOR Initiative may be also considered as the instrument of political influence. Besides an impressive infrastructure level of the project it is also realised in order to spread Chinese influence and linked (in a way of the linking power perhaps) other participating actors. Of course, the initiative is advertised as primarily inclusive. In the official version, the Chinese concept of inclusiveness means openness to others and cooperation on equal terms that will combine the interests and values of participating states [Yiwei 2016].

Many alternative examples of Chinese soft power can be found in the research literature. However, is the fact that 
the people in different states can see Chinese acrobatic shows (or any other cultural activities) may reflect Chinese soft power? Can it be considered that soft power - but taken seriously - can be generated through Chinese TV series, which the Chinese have provided in Cuba and many other states [Deng, Zhang 2009]? Is the 'flexibility in Chinese foreign policy' may be one of a sources of Chinese soft power [Mingjiang 2009]? Analyzing the valuable volume entitled Soft Power. China's Emerging Strategy in International Politics, I do question many of the examples presented by the Authors as they represent a different power than the soft one.

Earlier in this chapter I mentioned the possibility of distinguishing two other types of powers that complement the picture that is not filled by Nye's concept. In addition to the linking power, it is important to distinguish sharp power. Both theoretical categories work out for holistic understanding of the China's approaches to other political actors in the modern IR.

Sharp power, probably first time proposed in a $2017^{7}$, refers to 'piercing, penetrating and perforating' the political environment in other countries [Walker 2018]. The term is mainly used to explain the nowadays authoritarianisms, such as Russia or China, but in fact it is much flexible. To sharp power belongs those states activities that are intended to degrade the sovereignty or and integrity of other actors, i.e. governments, international institutions, its representatives and other entities bounded to them.

The key to distinguishing between soft and sharp power is how the political instruments are used. If a given measure does not attract to itself through its own attractiveness, but uses any form of coercion, it will not be a soft power instrument. For instance, if the Confucian Institutes promote and present the culture and history of China, then those instruments must be considered as soft, because there is no coercion. But if the Institute's employees prevent discussions on sensitive topics (e.g. Taiwan) and it is a procedural action, then it is a situation that concerns a coercion, and therefore - it should be assigned as an example of sharp power.

As everyone knows, good intentions are not decisive at the level of international relations (e.g. because there is probably no one intention that would be good for all of the actors). However, the differences between the various channels of political actions are visible. If a given foreign investment, which even aims to enrich culture and brighten economic well-being, is associated with the possibility of making the country's decision-makers dependent (linking power) or acquiring valuable intellectual rights (sharp power), then such investment cannot be an example of soft power. Of course, there are many other, more radical examples. There are several kinds of Chinese sharp power activities in Australia, a country very economically bounded with China. China is using its state-run media as well as private influencers to exert influence among Australia's elites, students, voters in various ways [Hamilton 2018; Hamilton 2018; Shao 2019].

A lot of work has been devoted to analyzing Nye's concept. Even for this reason, the assumption that soft power for some states may be neither indispensable, nor crucial, seems to be dubious. I do not agree with Christopher Walker when he states that 'we should avoid conceiving of sharp power as soft power's polar opposite. It is not the case that countries can wield either "sharp" or "soft" power, but not both' [Walker 2018; 18]. I do not think that any country can 'have' $0 \%$ of soft power. Obviously, it can be assumed that there is a disproportion between the use of soft and linking or sharp power. Realising that there is no methodological justification to conceive sharp and soft powers as a two opposite points - leads to consider that these powers are not also an antinomian dyads both are not on the same continuum. Concluding, these are two completely different powers.

Walker also sees that China's soft power problem is due to its authoritarian character [Walker 2018, 18-19]. John Fitzgerald observes that 'there is no boundary between politics and what passes for culture in contemporary China ${ }^{8}$. As the western world knows more and more about the Chinese public behavior control system (Social Credit System), it will be increasingly difficult to generate the classically understood soft power. In a country where - next to the market economy - authoritarian socialism is still keen, there will be not enough factors that would attract the West. Using sharp power, therefore, seems to be useful as well as coherent.

\section{Towards Multipolarity? The Liberal International Order Remains Uncertain}

Changes in the international liberal order are a topic that can be analyzed from many sides. Analysis of the ways and directions of superpowers' influence exerting illustrates that on the one hand, China will continue its political and economic expansion, using mainly sharp power, on the other hand, the United States - despite the need to

\footnotetext{
${ }^{7}$ Vide: International Forum for Democratic Studies, 'Sharp Power: Rising Authoritarian Influence” (Washington D.C.: National Endowment for Democracy, 2017), https://www.ned.org/wp-content/uploads/2017/12/Introduction-Sharp-Power-Rising-Authoritarian-Influence.pdf.

${ }^{8}$ Vide: Testimony Before The U.S. House Pemanent Select Committee On Intelligence, 'China's Foreign Influence And Sharp Power Strategy To Shape And Influence Democratic Institutions, https://www.ned.org/chinas-foreign-influence-and-sharp-power-strategyto-shape-andinfluence-democratic-institutions/.
} 
respond to the changing reality of political vibrancy - on the level of rational strategy does not decide on a more direct confrontation. The history of the U.S.-China trade war, which continues and extends without more significant deviations, suggests that the rivalry met its saddle point. Thus, the next emerging trends will illustrate global trends.

Many observers are wondering if China will replace the United States, and thus - will the liberal international order be changed? From a geopolitical point of view, this competition may or may not resemble the classic Thucydides or Kindleberger Traps. China's ever-growing power and the lack of previous reactions to stop this tendency, according to some, reveal fragments of 'geopolitical vacuum' that are waiting to be filled [Kristensen: 2017, 557-559].

The Kindleberger Trap, created by one of the architects of the Marshall Plan, as well as Thucydides Trap are theoretical constructs - in fact, in some cases related to game theory - that allow to discern the possible balance of power scenarios. The above models, however, are very general, but it is easy to see that they are able to be expanded.

1) The Kindleberger variant. In the face of the threatening, growing power of the aspiring superpower, the hegemonic power, accepting the advantage of its rival, gradually gives way.

a. Depreciation model. The position of the former hegemonic power in the system of IR is much less politically relevant.

b. Indifferency model. The position of the former hegemonic power in the system of IR has similar significance in terms of the political relevance and similar ability to influence and shape the international environment as a result of partial withdrawal from global leadership when at the same time the aspiring power is not able to gain a clearly dominant position.

c. Teselatic model (latin: tessellatus). The position of the former hegemonic power in the system of international relations becomes more regional and similar to the position of the other largest regional powers.

2) The Thucydides variant. In the face of the threatening, growing power of the aspiring power, the hegemonic power does not accept the potential change in the balance of power and thus it efforts to reduce the advantage of the rival.

a. Depreciation model. The position of the former hegemonic power is decreased to the level that it is not able to lead others and is forced to accept the changes.

b. Appreciation model. The position of the hegemonic power in the system of IR remains symmetrical or stronger than the position of the aspiring power.

In the face of danger, especially in the case of the appreciation model of the Thucydides Trap, maintaining the current hegemonic position is possible through the set of specific, preemptive actions in order to use the still existing advantage in selected sectors, e.g. economic, military, international relations. This advantage may be used to react to the occurrences on the level of political vibrancy and to maintain the current position, but not necessarily to expand it. Of course, the above goals can be effectively realised by off-shore balancing policies [Walt 2018], minimizing own exposure.

Within a positional changing of international order advances other substantial reversal. As John J. Mearsheimer points out that the liberal order may become an agnostic order within undermining the unipolarity [Mearsheimer 2019]. This may happen with or without the United States' will as a result of the emerging players influence. However, the discourse regarding changes in the international order is often conducted rather on the basis of theoretical possibilities (which I have done myself), than empirical premises revealing a superpowers' real interests. Thus, what is in the China's best interests?

First of all, as it was mentioned before, a time-delaying play is the essence. China does not need further engaged confrontation, because the passing time plays in their favour. China has been the world's largest exporter of goods since 2009. By dealing with internal problems through its specific methods, China is developing technologically and industrially. A quantity-based economy is slowly transforming into a quality-based economy. It can be seen, moreover, that this first model is gradually being transferred to the politically dependent countries of the region, e.g. Cambodia. As China develops, its regional position and zone of influence may expand and strengthen. With these on the one hand the need of cooperation with others will enlarge, on the other the needs of protecting owns interests. Although China uses sharp power and does not act transparently or honestly on many levels, at the same time it seeks a more democratized system of the IR. But China understands democratization of the IR in a much different way than West scholars do. For them it is mostly constraining the U.S. hegemonic behaviour [Foot 2006, 
77-90].

Secondly, by contrast to the USA, China does not need to be officially recognized as an equal or better. They do not even need a reshaping of the liberal international order being aware that international order is not just a product of concentration of powers. Instead of creating a new order ineptly, China will focus on the maximum exploitation of the current order. What is needed for its further development is access to other states for trade, investment, technology [Ikenberry 2018], and linking possibilities perhaps.

Thirdly, while the sources of American soft power (and American exceptionalism too) and the targets of its spreading might be limited, the Chinese sharp power operations may be progressed much faster due to the technological advances. The future of Sino-American relations will largely depend on technological development and work on the artificial intelligence. But even in this aspect - due to a limited semiconductors production [Ding: 2018] - China is doomed to cooperation and will not act to escalate.

However, the above issues do not mean that the liberal international order will still exist in the same formula. Once again it can be seen that the rational strategy level is different that the level of the political vibrancy. Even if China does not want to compete, it will have to do so in some areas. With the rapid development of China more and more Chinese national goals inevitably will have international consequences [Beeson, Watson 2019, 404-405]. The situation will not be helped by the fact that in order to avoid institutions' control, China, like Russia, prefers to pursue bilateral agreements wherever it is possible. Another problem is concerned with the rapid technology advancement. In the era of IT societies, the procedures for information management processes will be increasingly more significant, because they might be applied in a different, yet unknown, matters.

Paradoxically, within the rise of China the level of the USA-China interdependence will systematically grow up. Some theorists may not like it, and therefore proposes the return to old school methods like using hard power [Cohen 2016]. Cohen argues, for instance, that 'America's greatest challenge is China: to balance and prevent it from establishing hegemony over its neighbors and attempting to reshape an international order in its image' [Cohen 2016, p. 99]. America's hard power response to China would be completely irrational at many levels. First, because of the level of economic interdependence between the U.S. and China as well as China and European Union countries, such actions would met catastrophic economic results. Secondly, using hard power methods would acutely damage the U.S. political image on the international area, and therefore weakened its economic partnerships. Furthermore, we no longer live in the reality of sticks and carrots, and military conflict with China, apart from defensive actions et cetera, would only cause major problems leading to a significant change of the international order.

\section{SARS-COV-2 as a Catalyst for Political and Social Transitions}

Coronavirus pandemic may not only affect the future, but is able to shape the further international order. There is still too little data to indicate more certain differences. Noticeably the Chinese economy is doing better than the European or American economies. Still, however, it is unknown whether China will be able to repair its broken global supply chains completely and the ongoing pandemic fluctuations in the context of subsequent waves of infections can make it much harder. Domestic demand can drive Chinese economy, but not for a long term. On the other hand the case of COVID-19 is more about not who wins more, but who loses less. According to the analysis of data obtained from the IMF, apart from health issues (in this case, it is also difficult to fully trust Chinese sources), so far the economic crisis has affected the U.S. economy more than the Chinese economy. 


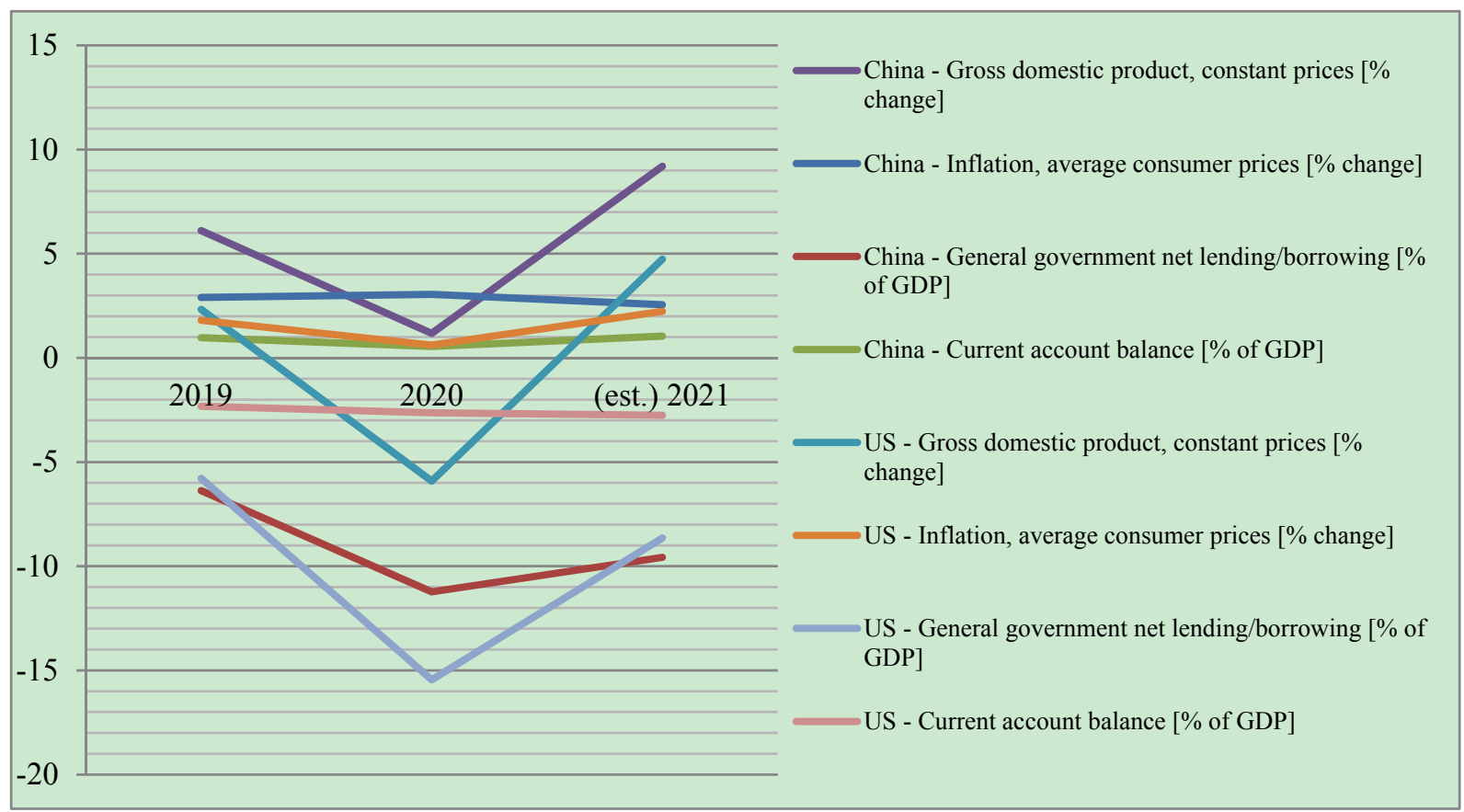

Chart 1.

Source: Author's analysis based on data retrieved from International Monetary Fund (IMF), https://www.imf.org/.

\section{Conclusions}

In the hereby work I emphasize that in order to know to what extent China is threatening the position of the United States, and thus the liberal international order as well, it is worth to analyze political actions - whether they represent the level of rational strategy, whether they belong to the sphere of political vibrancy. The main advantage of this theoretical approach is the ability that allows us to catch what is difficult to perceived, and to see the real nature of some phenomena.

Another methodological issue is the adaptation of theoretical concepts to describe empirical reality. The way China realizes international politics - with dubious and vague practices that seem to have procedural nature - led me to question the validity of China's soft power. Obviously, China has its soft power, generates it and influences others, although it is not the main channel. It is the linking power and sharp power that form the China's approach to the international order and other states. The presented struggle between America's smart power and China's sharp power will lead to some changes in international relations, maybe even some 'democratization' processes at the level of superpowers in the mean that is close to the multipolarity, rather than to escalated conflict. On the one hand, as John S. Nye states accurately, 'China is simultaneously too weak and too strong' at the same time [Nye 2017]. On the other hand, on the level of rational strategy the U.S. seems to be renegotiating or withdrawing not only from the important partnerships, e.g. Trans-Pacific Partnership, North American Free Trade Agreement, but from the hegemonic, widespread power and responsibilities.

The issue of the liberal international order affects a number of other concerns. Sino-American rivalry is a question mark over Russia's position, whose relative neutrality in a possible conflict would be a huge asset for the U.S. Other problems are the issue of the so-called rogue states (North Korea, Iran), fast developing countries (India, Brazil), and the further position of post-Brexit European Union, with particular emphasis on Germany, which, on the one hand, has been facing a huge challenge related to various contentious issues (Chinese export, OBOR Initiative etc.), on the other - have never been diplomatically this far away from the United States [Herszenhorn 2020].

As it was stated earlier, the further world will need a cooperation between states, regional powers and superpowers. But the cooperation - as well as the lack of cooperation - is always at the cost of something. In this case it may be a decreased political influence of the United States resulted in the processes of a gradual fragmentation of world power. 


\section{References}

Alden, Ch., \& Jiang, L. (2019). Brave new world: debt, industrialization and security in China-Africa relations. International Affairs, 95(3), 641-657. https://doi.org/10.1093/ia/iiz083

Allison, G. (2017). Destined for War: Can America and China Escape Thucydides's Trap? Boston - New York, Houghton Mifflin Harcourt Publishing Company.

Armitage, R. L., \& Nye, J. S. [Coachers]. (n.d.). CSIS Commission on smart power. A smarter, more secure America. Washington, The CSIS Press.

Beeson, M., \& Watson, N. (2019). Is International Leadership Changing Hands or Disappearing? China and the USA in Comparative Perspective. Asian Perspective, 43(2), 387-415. https://doi.org/10.1353/apr.2019.0015

Bennett, J. (2010). Vibrant Matter. A Political Ecology of Things. Durham, Duke University Press. https://doi.org/10.1215/9780822391623

Brand Finance. (2019). Nation Brands 2019. The annual report on the most valuable and strongest nation brands. London. Retrieved from https://brandirectory.com/rankings/nation-brands

Brzeziński, Z. (1997). The Grand Chessboard - American Primacy and Its Geostrategic Imperatives. New York, Basic Books.

Carrai, M. A. (2019). China's Malleable Sovereignty along the Belt and Road Initiative: The Case of the 99-Year Chinese Lease of Hambantota Port. New York University Journal of International Law, 51(4), 1061-1099. https://doi.org/10.2139/ssrn.3346116

Chen, W., Chen. X., Hsieh, Ch., \& Song, Z. (2019). A Forensic Examination of China's National Accounts. Brookings Papers on Economic Activity, 1, 77-141. https://doi.org/10.1353/eca.2019.0001

Cohen, E. A. (2016). The Big Stick. The Limits of Soft Power \& the Necessity of Military Force. New York, Basic Books.

Deng, X., \& Zhang, L. (2009). China's Cultural Exports and its Growing Cultural Power in the World [chapter]. In Mingjiang, Le (Ed.), Soft Power. China's Emerging Strategy in International Politics (pp. 143-162). Plymouth, Rowman \& Littlefield Publishers Inc.

Deudney, D. (2017). Hegemony, nuclear weapons, and liberal hegemony. Chapter 7. In Ikenberry, J. G. (Ed.), Power, Order and Change in World Politics (pp. 195-232). Cambridge, Cambridge University Press. https://doi.org/10.1017/CBO9781139680738.011

Deudney, D. H. (2007). Bounding Power. Republican Security Theory from the Polis to the Global Village. Princeton - Oxford, Princeton University Press.

Deudney, D., \& Ikenberry, J. (2017). Realism, Liberalism and the Iraq War. Survival. Global Politics and Strategy, 26(7), 7-26. https://doi.org/10.1080/00396338.2017.1349757

Dueck, C. (2015). The Obama Doctrine. American Grand Strategy Today. New York, Oxford University Press.

Foot, R. (2006). Chinese strategies in a US-hegemonic global order: accommodating and hedging. International Affairs, 82(1), 77-94. https://doi.org/10.1111/j.1468-2346.2006.00516.x

Frazier, D., \& Stewart-Ingersoll, R. (2010). Regional powers and security: A framework for understanding order within regional security complexes. European Journal of International Relations, 16(4), 731-753. https://doi.org/10.1177/1354066109359847

Friedman, J., Chase-Dunn, \& Christopher, K. (2005). Hegemonic Decline: Present and Past. Boulder, Paradigm Publishing.

Grix, J., \& Houlihan, B. (2014). Sports Mega-Events as Part of Nation's Soft Power Strategy: The Cases of Germany (2006) and the UK (2012). British Journal of Politics and International Relations, 16(4), 572-596. https://doi.org/10.1111/1467-856X.12017

Hamilton, C. (2018). Australia's Fight Against Chinese Political Interference. What Its New Laws Will Do. Foreign Affairs.

Hamilton, C. (2018). Silent Invasion: China's Influence in Australia. Richmond, Hardie Grant Books.

Herszenhorn, D. M. (2020). Trump Europe Strategy: Nothing. Politico. Retrieved from https://www.politico.eu/article/donald-trump-eu-strategy-nothing-g7-summit-angela-merkel/

Ikenberry, J. G. (2004). Soft Power: The Means to Success in World Politics [review]. Forreign Affairs, 83(3), 
136-137. https://doi.org/10.2307/20033985

Ikenberry, J. G. (2017). Power, Order and Change in World Politics. Cambridge, Cambridge University Press.

Ikenberry, J. G. (2018). Why the Liberal World Order Will Survive. Ethics \& International Affairs, 32(1), 17-29. https://doi.org/10.1017/S0892679418000072

Juneau, T. (2019). The Enduring Constraints on Iran's Power after the Nuclear Deal. Political Science Quarterly, 134(1), 39-61. https://doi.org/10.1002/polq.12869

Kalimuddin, M., \& Anderson, D. A. (2018). Soft Power in China's Security Strategy. Strategic Studies Quarterly, 12(3), 114-141.

Keohane, R. O., \& Nye, J. S. (1978). Power and Interdependence. World Politics in Transition. Boston, Little Brown.

Krauthammer, Ch. (2002). The Unipolar Moment Revisited. The National Interest, (70), 5-18.

Kristensen, P. M. (2017). After Abdication: America Debates the Future of Global Leadership. Chinese Political Science Review, 2, 550-566. https://doi.org/10.1007/s41111-017-0078-7

Lindbekk, T. (1992). The Weberian Ideal-type: Development and Continuities. Acta Sociologica, 35(4), 285-297. https://doi.org/10.1177/000169939203500402

Mearsheimer, J. J. (2019). Bound to Fail. The Rise and Fall of the Liberal International Order. International Security, 43(4), 7-50. https://doi.org/10.1162/isec_a_00342

Mingjiang, L. (Ed.). (2009). Soft Power. China's Emerging Strategy in International Politics. Plymouth, Rowman \& Littlefield Publishers Inc.

Miskimmon, A., O’Loughlin, B., \& Roselle, L. (2014). Strategic narrative: A new means to understand soft power. Media, War \& Conflict, 7(1), 70-84. https://doi.org/10.1177/1750635213516696

Morkevicius, V., \& Lupton, D. (2020). Was the killing of Qassem Soleimani justified? Retrieved from https://politicalviolenceataglance.org

Nye, J. S. (1990). Bound to Lead: The Changing Nature of American. New York, Basic Books.

Nye, J. S. (2002). The Paradox of American Power: Why the World's Only Superpower Can't Go it Alone. New York, Oxford University Press.

Nye, J. S. (2004). Soft Power and American Foreign Policy. Political Science Quarterly, 119(2), 255-270. https://doi.org/10.2307/20202345

Nye, J. S. (2004a). Power in the Global Information Age: From Realism to Globalization. London, Routledge. https://doi.org/10.4324/9780203507292

Nye, J. S. (2004b). Soft power: The means to success in world politics. New York, Public Affairs.

Nye, J. S. (2012). Understanding International Conflicts: An Introduction to Theory and History. New York, Longman.

Nye, J. S. (2017). Will the Liberal Order Survive? The History of an Idea. Foreign Affairs, 96(10), 10-16.

Nye, J. S. (2019). The rise and fall of American hegemony from Wilson to Trump. International Affairs, 95(1), 6380. https://doi.org/10.1093/ia/iiy212

Otmazgin, N. K. (2012). Geopolitics and Soft Power: Japan's Cultural Policy and Cultural Diplomacy in Asia. Asia-Pacific Review, 19(1), 37-61. https://doi.org/10.1080/13439006.2012.678629

Pacuła, P. (2015). Relacje Chin z wybranymi państwami w Azji Południowo-Wschodniej i Wschodniej i ich wpływ na bezpieczeństwo w regionie. Bezpieczeństwo Narodowe, 2.

Persson, P., \& Zhuravskaya, E. (2011). Elite Capture in the Absence of Democracy: Evidence from Backgrounds of Chinese Provincional Leaders. SSRI Electronic Journal. https://doi.org/10.2139/ssrn.1506709

Rubin, E. (1997). Rational States? Virginia Law Review, 83(7), 1433-1451. https://doi.org/10.2307/1073763

Sayamov, N. Y. (2013). Education as a global «soft power» for sustainable development. Campus-Wide Information Systems, 30(5), 346-357. https://doi.org/10.1108/CWIS-08-2013-0040

Shao, J. (2019). Exploring China's «Sharp Power»: Conceptual Deficiencies and Alternative. Transcommunications, 6(2), 129-148. 
Shullman, D. (Ed.). (2019). Chinese Malign Influence and the Corrosion of Democracy. An Assessment of Chinese Interference in Thirteen Key Countries. Washington, International Republican Institute.

Trilokekar, R. D. (2010). International education as soft power? The contributions and challenges of Canadian foreign policy to the internalization of higher education. Higher Education, 59(2), 131-147. https://doi.org/10.1007/s10734-009-9240-y

Turner, O. (2014). American Images of China. Identity, power, policy. New York, Routledge. https://doi.org/10.4324/9781315776705

Walker, C., \& Ludwig. (2017). The meaning of sharp power: How authoritarian states project influence. Foreign Affairs, 16.

Walker, Ch. (2016). The Hijacking «Sharp Power». Journal of Democracy, 27(1), 49-63. https://doi.org/10.1353/jod.2016.0007

Walker, Ch. (2018). What is «Sharp Power»? Journal of Democracy, 29(3), 9-23. https://doi.org/10.1353/jod.2018.0041

Walt, S. M. (2018). The Hell of Good Intentions. America's Foreign Policy Elite and the Decline of U.S. Primacy. New York, Farrar, Straus and Giroux.

Weber, M. (1949). Methodology of Social Sciences. Glencoe, Free Press.

Wübekke, M. et al. (2016). Made in China 2025. The making of a high-tech superpower and consequences for industrial countries. MERICS: Mercator Institute for China Studies.

Yiwei, W. (2016). The Belt and Road Initiative. What will China offer the world in its rise? Beijing, New World Press.

\section{Copyrights}

Copyright for this article is retained by the author(s), with first publication rights granted to the journal.

This is an open-access article distributed under the terms and conditions of the Creative Commons Attribution license (http://creativecommons.org/licenses/by/4.0/). 